\title{
Journal of Operational Meteorolog. Article \\ Utilizing Crowd-Sourced Rainfall and Flood Impact Information to Improve the Analysis of the North Central Gulf Coast Flood Event of April 2014
}

\author{
W. SCOTT LINCOLN \\ National Weather Service Lower Mississippi River Forecast Center, Slidell, Louisiana \\ RACHELLE F. L. THOMASON \\ University of New Orleans Department of Earth \& Environmental Sciences, New Orleans, Louisiana \\ MEGAN STACKHOUSE \\ National Weather Service, Grand Junction, Colorado \\ DAVID S. SCHLOTZHAUER \\ National Weather Service Lower Mississippi River Forecast Center, Slidell, Louisiana
}

(Manuscript received 16 September 2016; review completed 30 January 2017)

\begin{abstract}
In late April 2014, a slow-moving cold front exiting the central plains produced a large area of showers and embedded thunderstorms across the southeastern United States. In the lower Mississippi Valley, a line of heavy thunderstorms initially developed the evening of 28 April 2014 with subsequent thunderstorm outbreaks for the next two evenings centered on residual thunderstorm outflow boundaries. This paper presents a case study to illustrate the importance of crowd sourcing rainfall observations and storm reports to establish an accurate historical context for extreme hydrologic events. For this April 2014 event, researchers collected additional reports of rainfall and flooding impacts from private data networks and social media to augment traditional National Weather Service data sources. As a result of this data collection, the multi-source analysis for the 3-d period from 29 April to 01 May showed areas near Pensacola, Florida, received at least $50.8 \mathrm{~cm}(20$ in) of rainfall with a point maximum of $73.15 \mathrm{~cm}(28.8 \mathrm{in})$ near Lillian, Alabama. Researchers then computed an average recurrence interval for the multi-source storm total rainfall as a 1-in-500-yr event, although some point locations reached a 1-in-1000-yr event for shorter rainfall durations between $3 \mathrm{~h}$ and $24 \mathrm{~h}$. The additional reports retrieved through crowd-sourcing to compile this multi-source analysis were essential to establish an accurate and precise accounting of rainfall magnitude and associated impacts.
\end{abstract}

\section{Introduction}

Over the course of three days beginning the evening of 28 April 2014, a historic rainfall event occurred from 29 April to 01 May 2014 that significantly impacted areas from Mobile, Alabama, to Pensacola, Florida. A rain gauge near Lillian, Alabama, reported a 3-d rainfall total of $73.15 \mathrm{~cm}$ (28.8 in), most of which occurred over a 48-h period. Near Pensacola, Florida, many locations received at least $50.8 \mathrm{~cm}$ (20 in) of rain. This rain event was a result of a weakening cold front moving slowly across the lower Mississippi Valley. In late April 2014, rainfall from an initial area of showers and embedded thunderstorms created saturated soil conditions that set the stage for the majority of rainfall from additional thunderstorm activity to become runoff. Recurrent thunderstorm activity resulted in major flooding across a five-county area from coastal Alabama into the western Florida Panhandle.

There are many ways to categorize flood event severity. The National Weather Service (NWS) describes the severity of flood events using a scale

Corresponding author address: W. Scott Lincoln, 62300 Airport Road, Slidell, LA 70460 
defined by impacts. The NWS uses the terms minor, moderate, major, and record, each with a specific definition of the impact(s) associated with the term. As an example, the NWS defines major flooding as "extensive inundation of structures and roads" along with "significant evacuations of people and/or transfer of people to higher elevations" (NWS 2012). For this discussion of multi-source information, it is important to understand that the NWS ties these impacts to an official NWS river forecast point. The flood category is not necessarily the same at all locations on a river reach, which is a critical communication point for citizens in large urban areas where a river reach may have multiple NWS forecast points throughout the metropolitan area and thus different flood impacts for a particular river stage.

Other terms to characterize the severity of a flood event include monetary damage amounts, extent of the area that is impacted, casualties, and the average recurrence interval (ARI; sometimes also referred to as "return period") for streamflow and/or rainfall. The ARI indicates the average time between events of a given magnitude, when averaged over a very long period of time. The annual exceedance probability (AEP) of an event - the chance an event of the given magnitude will occur within any given year - is related to ARI and is more commonly used to describe the rarity of an event to the public. AEP is equal to one divided by the ARI. Although events are most often categorized by streamflow ARI, recent studies have attempted to describe rainfall in terms of an ARI/AEP (Parzybok et al. 2011; Parzybok and Shaw 2012; Lincoln 2014).

This case study shows that it is essential to increase the density of observations/reports to capture the full magnitude of impacts and to accurately calculate ARI/ AEP values. The typical method of receiving reports of flooding impacts by the NWS is through communication with law enforcement, emergency managers, or other trained weather spotters. Reports of flooding collected through this method are often sparse, even for significant events. Some work has been already done to illustrate the utility of collecting flood impact reports from additional sources. Gourley et al. (2010) presented on the flash flood reports collected by the Severe Hazards Analysis and Verification Experiment (SHAVE) using crowd-sourcing, a method utilizing data from a large array of independent persons and groups that are often left unused beyond the general public. Rather than waiting to receive reports of weather impacts, SHAVE researchers actively looked for severe weather impacts.
Similarly, a substantial portion of the meteorological data and flood impacts used in our study were obtained through data mining of multiple private meteorological networks. Inclusion of non-traditional reports that passed Quality Assurance/Quality Control (QA/ QC) procedures increased the density of rainfall data points by fivefold. Data mining of various social media platforms over a multi-week period yielded additional "reports" of flood impacts including text descriptions, photographs, and videos.

We will first examine the meteorological features that contributed to the severity of the event in section 2. Section 3 outlines the process to identify rainfall data sources, QA/QC procedures, and analysis of gridded rainfall fields. Section 3 concludes with a discussion and presentation of ARI/AEP calculations for different rainfall durations. Section 4 presents flood reports and impacts. Section 5 highlights the importance of additional rainfall reports to ARI/AEP calculations that support the conclusions presented in section 6 .

\section{Meteorological Synopsis}

\section{a. Synoptic analysis}

A weakening cold front, extending from an area of surface low pressure in the Midwest, produced two waves of excessive rainfall. During the event, abundant moisture was available along the northern Gulf of Mexico with precipitable water (PWAT) values ranging from the 90th percentile to maximum observed for the month of April. The origins of the first wave of rainfall can be traced back to 28 April 2014 when the cold front was stretched from Missouri to Texas. At 1200 UTC the surface low was analyzed near Omaha, Nebraska, with a broken line of thunderstorms on-going ahead of the cold front from near Memphis, Tennessee, to the vicinity of Shreveport, Louisiana. At 1900 UTC, thunderstorms redeveloped along an outflow boundary from the decaying line of morning thunderstorms. Over the course of the afternoon and evening, the line of storms propagated very slowly to the southeast as the parent low pressure area remained nearly stationary and the trailing cold front weakened substantially. This line of thunderstorms passed through the Mobile and Pensacola areas from 0500 UTC to 1000 UTC on 29 April 2014. Between approximately 1000 UTC and 1600 UTC an outflow boundary was produced along the Gulf Coast. Remnants of the decaying cold front were situated to the northwest over northern Louisiana to northern Mississippi. Between 1600 UTC and 1700 
UTC a new cluster of thunderstorms began to develop along the southern end of the outflow boundary near the Mississippi coast. Over the following 19-h period, thunderstorm activity increased in intensity and evolved into a Mesoscale Convective System that remained nearly stationary. Finally, by 1300 UTC 30 April, thunderstorm activity began moving eastward into the central Florida Panhandle.

The first wave of rainfall was the more progressive of the two, but still produced rainfall heavy enough to cause minor flooding. Strong diffluent jet structure aloft combined with moisture convergence and instability between the surface and the 850-mb level supported a line of heavy thunderstorms that moved through Mississippi, Alabama, and Florida during the overnight hours into 29 April 2014 (Fig. 1A-B). Slow storm motion enhanced rainfall totals. Regions to the east remained uncapped with Most Unstable CAPE values more than $3000 \mathrm{~J} \mathrm{~kg}-1$; this created a primed environment for later development during the afternoon. Preceding the first wave of rain, $850-\mathrm{mb}$ moisture transport values and PWAT at 0000 UTC on 29 April 2014 (Fig. 1C-D) were $4 \mathrm{~cm}$ (1.6 in) and $20 \mathrm{~m} \mathrm{~s}-1$ (38.9 kt), respectively, from the Mississippi coast to the Western Panhandle of Florida.

Although reported instances of flooding were categorized as minor, this first wave of rainfall produced saturated soils creating the necessary antecedent conditions for flash flooding to occur with additional rainfall. Mesoscale conditions at 1200 UTC 29 April 2014 were not suggestive of another heavy rainfall event as the outflow boundary associated with the earlier convection had pushed offshore (Fig. 2A-B) and the $850-\mathrm{mb}$ moisture transport values dropped to $10 \mathrm{~m}$

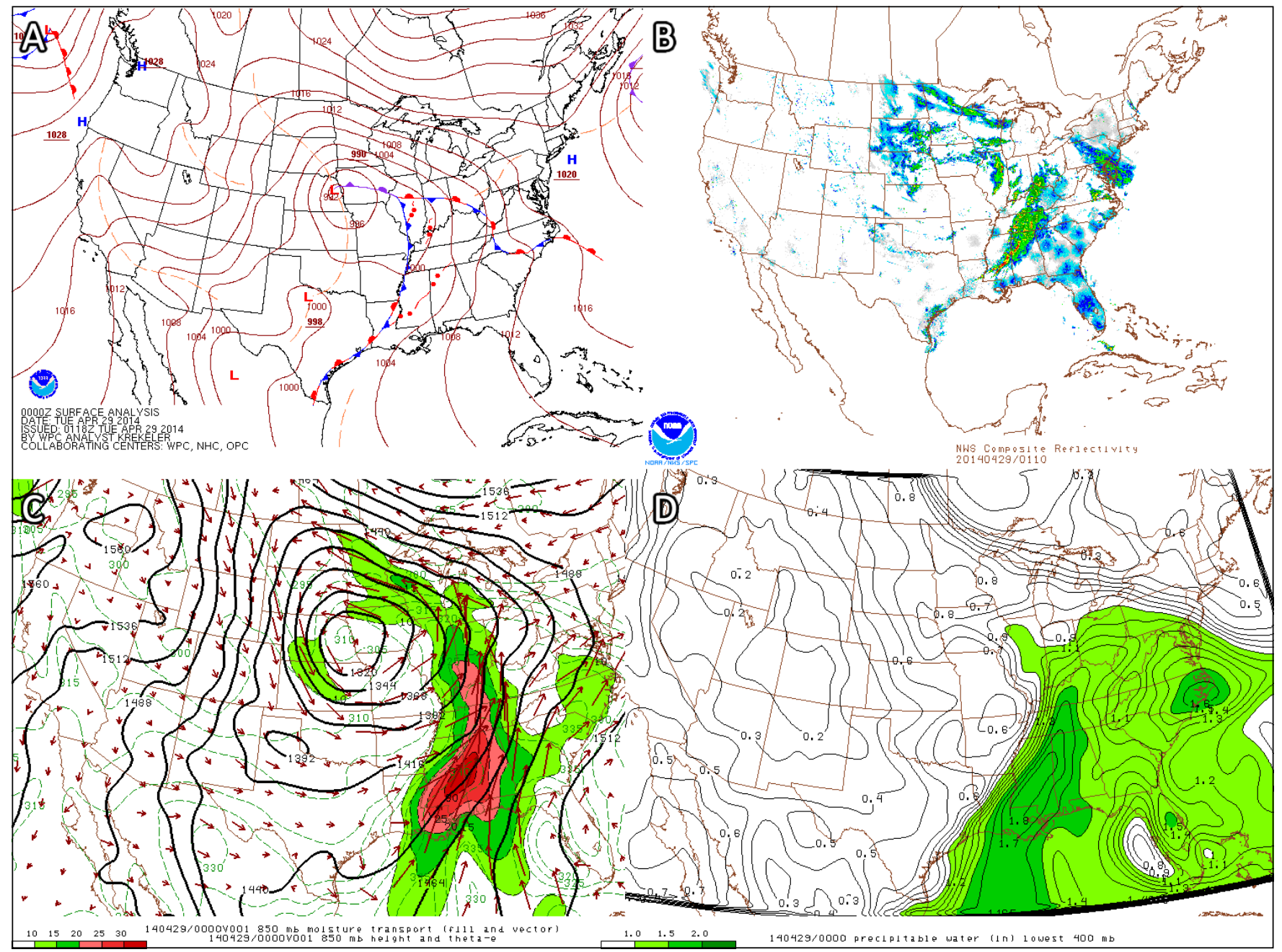

Figure 1. 0000 UTC 29 April 2014 surface analysis (A), radar mosaic (B), 850-mb moisture transport (C), and precipitable water values (D) from the Storm Prediction Center Mesoanalysis Archive (http://www.spc.noaa.gov/ exper/archive/events/). Click image for an external version; this applies to all figures hereafter. 
s-1 (19.4 kt; Fig. 2C). However, PWAT values to the south of the Alabama and Florida coastline began to rise, reaching values up to $4.8 \mathrm{~cm}$ (1.9 in) with values of 4.1 to $4.6 \mathrm{~cm}$ (1.6 to $1.8 \mathrm{in}$ ) spanning from Mobile to Pensacola (Fig. 2D).

The second wave of rainfall began during the afternoon of 29 April 2014 and lasted until the morning hours of 30 April 2014. Thunderstorms initially developed over the lower Mississippi Valley and eastern Gulf of Mexico in response to increasing flux of moisture and instability, with storms propagating northeastward ahead of the cold front. By 0000 UTC 30 April the cold front was located in southeastern Louisiana and thunderstorms were widespread across coastal areas to the east (Fig. 3A-B). Over the course of the afternoon, the area of high PWAT values had migrated northwards and increased to $4.8 \mathrm{~cm}$ (1.9 in) along the gulf coast
(Fig. 3D) with $850-\mathrm{mb}$ moisture transport values of $25 \mathrm{~m} \mathrm{~s}-1$ (48.6 kt; Fig. 3C). Sounding data from NWS Weather Forecast Office (WFO) New Orleans in Slidell, Louisiana (LIX), indicated an observed PWAT value of $5.0 \mathrm{~cm}$ (1.98 in) and sounding data from NWS WFO Tallahassee, Florida (TLH), observed a PWAT value of $3.7 \mathrm{~cm}$ (1.47 in); both values were at or above the 90th percentile for that day of the year, with LIX being near a daily record (Fig. 4), based upon Storm Prediction Center sounding climatology (www.spc.noaa.gov/ exper/soundingclimo). As the frontal system continued to move southeastward into areas of higher tropical moisture, multi-celled storms became more linear in nature, aligned with the upper flow, and continued to train over coastal locations into the overnight hours.

PWAT values continued to increase to 4.4 to $5.1 \mathrm{~cm}$ (1.75 to 2 in) across the region by 0400 UTC. Upper
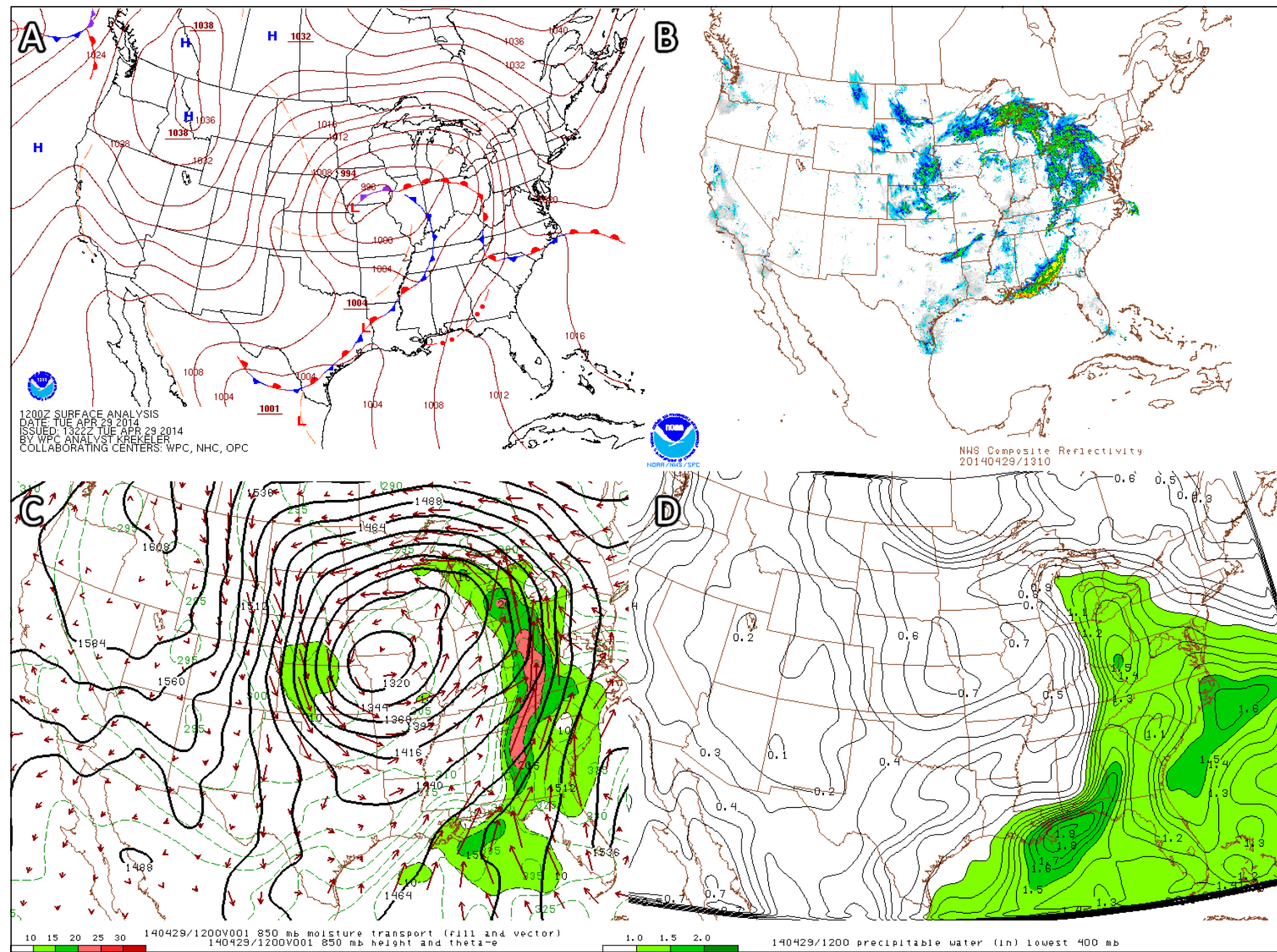

Figure 2. 1200 UTC 29 April 2014 surface analysis (A), radar mosaic (B), 850-mb moisture transport (C), and precipitable water values (D) from the Storm Prediction Center Mesoanalysis Archive (http://www.spc.noaa.gov/ exper/archive/events/). 


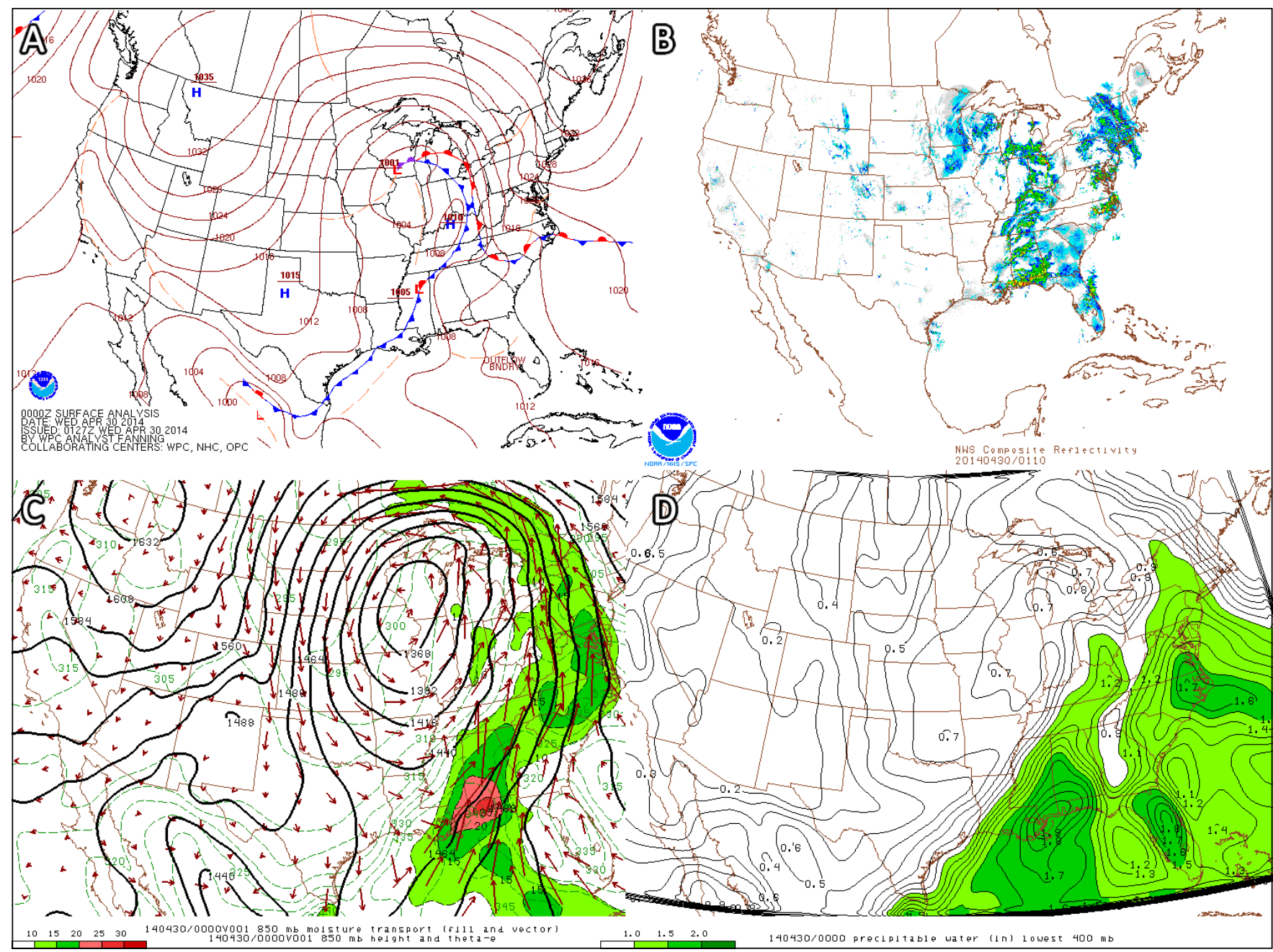

Figure 3. 0000 UTC 30 April 2014 surface analysis (A), radar mosaic (B), 850-mb moisture transport (C), and precipitable water values (D) from the Storm Prediction Center Mesoanalysis Archive (http://www.spc.noaa.gov/ exper/archive/events/).

divergence along the left-exit region of the developed sub-tropical jet added additional support for cell development into the overnight hours while PWAT values increased to more than $5.1 \mathrm{~cm}$ ( 2 in) by 0800 UTC. Heavy rainfall ceased across southern Alabama and Mississippi by 1100 UTC on 30 April 2014 as the southwesterly flow propagated eastward in tandem with the cold front. The atmosphere remained moist with PWAT values of more than $5.1 \mathrm{~cm}$ ( 2 in) across the western portion of the Florida Panhandle and $850-\mathrm{mb}$ moisture transport values of $25 \mathrm{~m} \mathrm{~s}-1$ (48.6 kt; Fig. 5).

Redevelopment of heavy rainfall continued along the western flank and was still supported by southwesterly inflow. The enhanced upper divergence region along the left-exit region of the sub-tropical jet and strong isentropic lift over a rain-cooled outflow boundary continued to add support for the persistent redevelopment of storms into the late morning hours. Data from 0000 UTC on 1 May 2014 indicated that the threat for heavy rainfall had propagated eastward as the maximum $850-\mathrm{mb}$ transport values and PWAT values shifted from the Alabama and Western Florida Panhandle coastline to Georgia and the Florida Peninsula (Fig. 6).

\section{b. Radar Analysis}

At approximately 0500 UTC on 29 April 2014, the first round of rain began in Mobile and arrived in Pensacola approximately $3 \mathrm{~h}$ later. This intense band of storms persisted until 1200 UTC (Fig. 7). The second wave of storms began to develop early afternoon at approximately 1800 UTC along the $850-\mathrm{mb}$ subtropical jet. This continued cycle of thunderstorm 

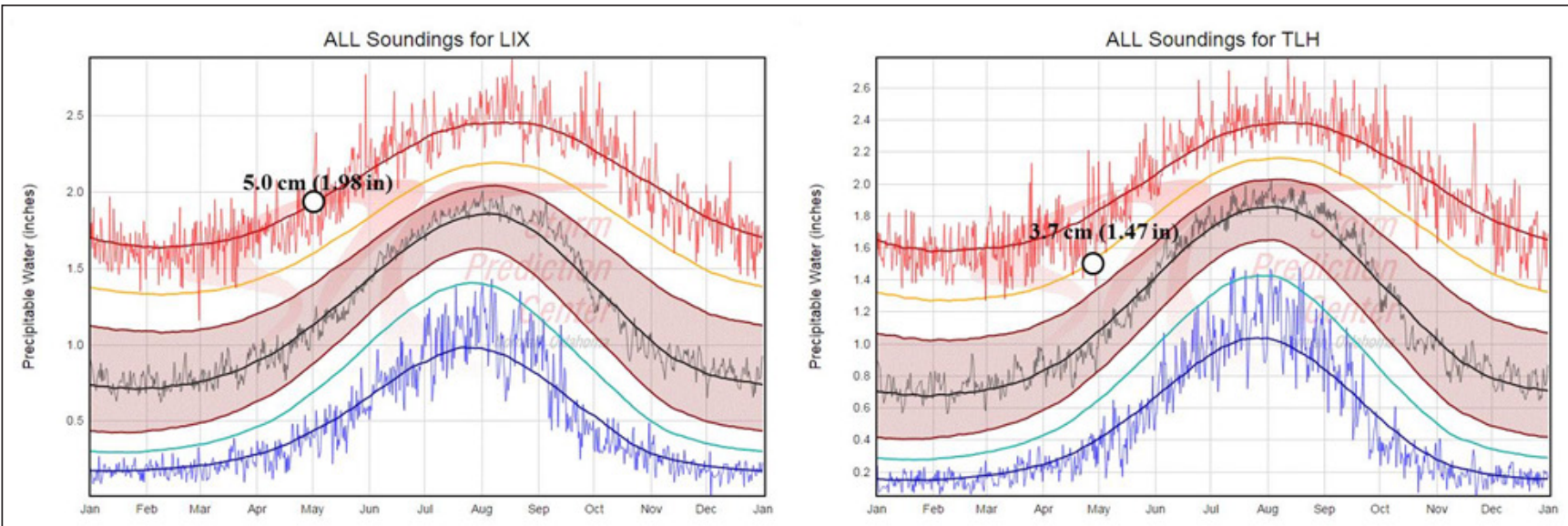

Figure 4. Precipitable water climatology values from soundings from NWS WFO New Orleans/Baton Rouge, Louisiana (left), and NWS WFO Tallahassee, Florida (right). Observed precipitable water values for 0000 UTC 30 April 2014 are indicated by white circles. The Mobile, Alabama, and Pensacola, Florida, areas are approximately halfway between these two sounding locations. From the Storm Prediction Center Sounding Page (http://www.spc. noaa.gov/exper/soundingclimo/).

redevelopment ahead of the slow-moving cold front persisted from 1230 UTC on 29 April 2014 until 1300 UTC on 30 April 2014 (Fig. 8), with some locations experiencing nearly continuous thunderstorm activity for a period of at least $8 \mathrm{~h}$.

At approximately 1900 UTC 29 April, KMOB radar (located just west of Mobile, Alabama) was damaged by a direct lightning strike and remained offline for the remainder of the rainfall event. The loss of data from KMOB - the closest radar site to the area of heaviest rainfall - likely reduced the quality of radarderived rainfall estimates, increasing the need for gauge observations. After this point, the next closest radar site became KEVX (located at the east end of Eglin Air Force Base near Defuniak Springs, Florida) and this resulted in the lowest radar angle elevation increasing from approximately 900 to $1500 \mathrm{~m}$ (3000 to $5000 \mathrm{ft}$ ) to approximately 2100 to $2700 \mathrm{~m}$ (7000 to $9000 \mathrm{ft})$.

\section{Rainfall Estimation}

Rainfall data obtained from various sources were analyzed for the duration of the event spanning from Mobile, Alabama, to the western portion of the Florida Panhandle. Spatial data were categorized as either point source data or gridded data. Point source data were obtained from official source and private source rain gauges. Gridded data were obtained via remotely sensed estimates from Multi-Radar Multi-Sensor (MRMS) data. Gridded data for this event were also bias-corrected with the use of point rain gauge data, some of which were obtained post-event. This section elaborates on the different types of rainfall data used in this analysis. First is point rainfall data, then quality control (QC) of rainfall observations, followed by gridded rainfall estimates.

\section{a. Point Rainfall Data}

Data obtained from official government sources include the Federal Aviation Administration (FAA; automated stations located at airports), National Weather Service/National Oceanic and Atmospheric Administration (NWS/NOAA; manual-reporting daily stations used for NWS climate records), United States Geological Survey (USGS; automated stations colocated with stream gauges), and the United States Forest Service (USFS; automated stations). Data obtained from private sources include Community Collaborative Rain Hail and Snow network (CoCoRaHS; manualreporting stations monitored by a volunteer observer network), Center for Hurricane Intensity and Landfall Investigation mesonet at the University of South Alabama (CHILI; automated stations operated by university research projects), Weather Underground Personal Weather Station (WU PWS; automated stations of varying quality and reliability operated by private persons) network, Davis Instruments (Davis; automated stations of varying quality and reliability operated by private persons), Earth Networks (formerly known as AWS) WeatherBug (AWS; automated stations of varying quality and reliability operated by private 

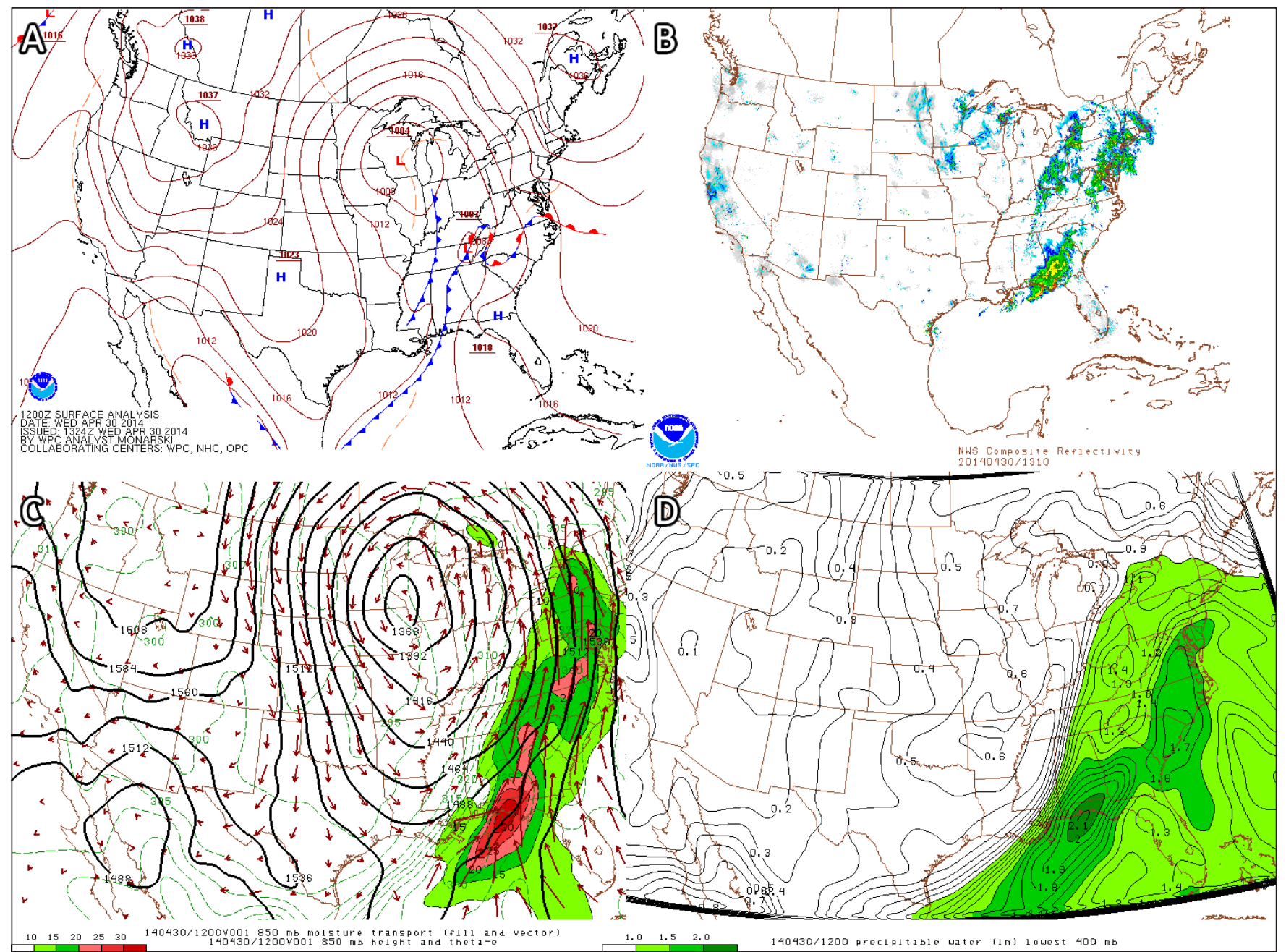

Figure 5. 1200 UTC 30 April 2014 surface analysis (A), radar mosaic (B), 850-mb moisture transport (C), and precipitable water values (D) from the Storm Prediction Center Mesoanalysis Archive (http://www.spc.noaa.gov/ exper/archive/events/).

persons), and data obtained from the public via social media requests (bucket survey; manually estimated water depths collected in rain gauges and empty containers by the public with a wide range of quality). Figure 9 shows the 3 -d storm total rainfall ending 1200 UTC 01 May 2014 for each of the official and private gauges that did not fail quality control (section 3b), differentiated by the source network.

Rainfall data from FAA, NWS/NOAA, USGS, and USFS were obtained from the Iowa Environmental Mesonet data archive (mesonet.agron.iastate.edu/sites/ locate.php). Data from CoCoRaHS were obtained from www.cocorahs.org/ViewData. WU PWS sites were obtained from the Weather Underground archive (www.wunderground.com) after selecting relevant sites using methods from "2012 Southeast Louisiana and Southern Mississippi Flooding Due to Hurricane Isaac"
(Lincoln et al. 2013). Data from Davis Instruments were more difficult to obtain; the authors collaborated with Russ Heilig, Vice President of Business Development, who worked with his staff to manually extract the requested data for each site. Once complete, collected data included 13 FAA locations, 23 NWS/NOAA locations, four USGS locations, two USFS locations, 16 CHILI locations, 44 WU PWS locations, 37 Davis locations, 64 CoCoRaHS locations, 42 AWS locations, and 11 public reports. Figure 9 depicts locations of all point rainfall data for the duration of the event. Many locations surrounding Mobile reported rainfall totals in excess of $25.4 \mathrm{~cm}$ (10 in). More extreme rainfall totals are reported in areas surrounding Perdido Bay, where the maximum rainfall total was $73.1 \mathrm{~cm}(28.8$ in), as reported by a private weather station near Lillian, Alabama. 


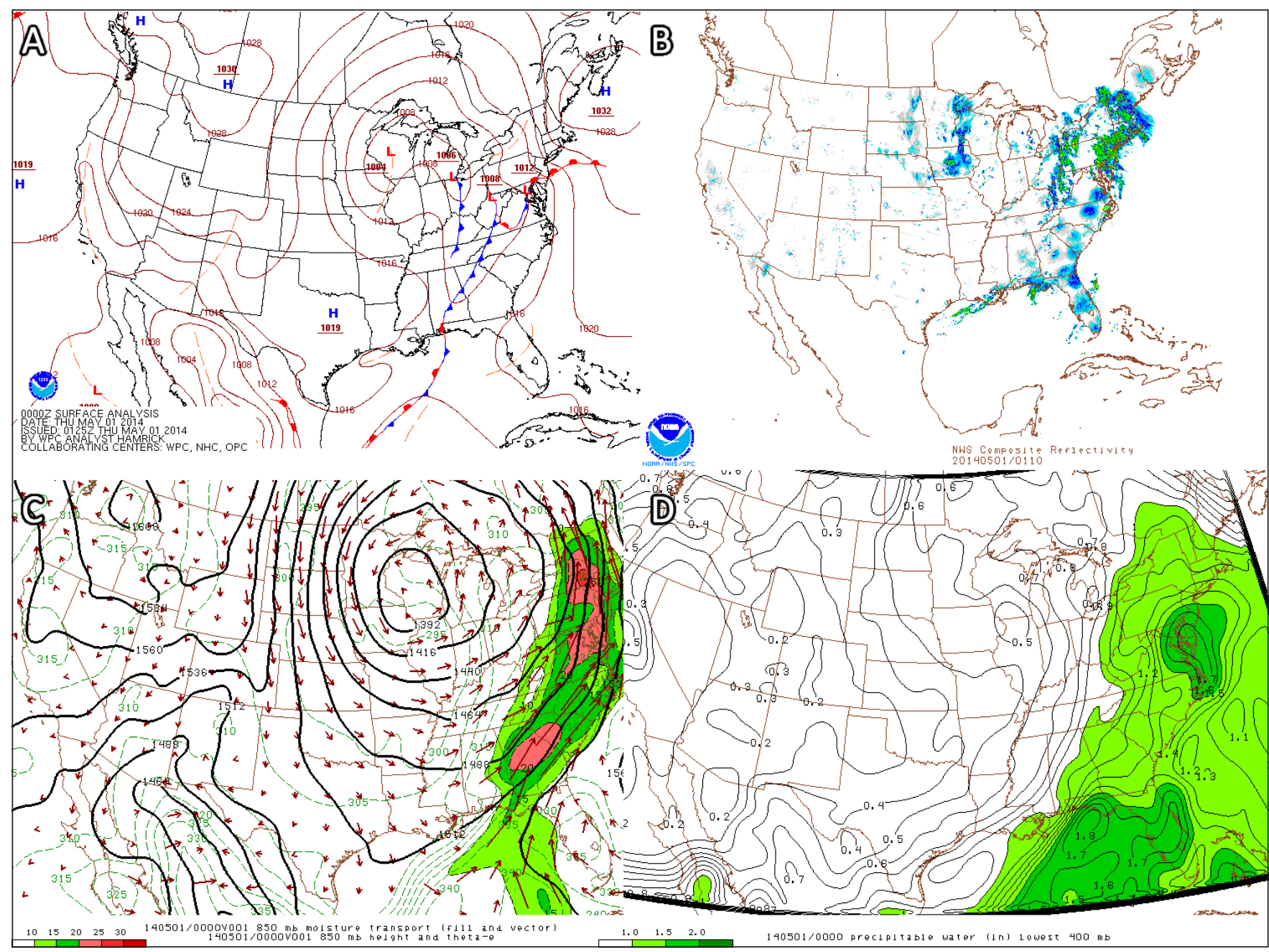

Figure 6. 0000 UTC 01 May 2014 surface analysis (A), radar mosaic (B), 850-mb moisture transport (C), and precipitable water values (D) from the Storm Prediction Center Mesoanalysis Archive (http://www.spc.noaa.gov/ exper/archive/events/).

\section{b. Quality Control of Point Rainfall Data}

To improve the quality of the point rainfall estimates that were used to bias-correct the radar estimate, a gauge quality check process was performed. There are few widely accepted, objective guidelines for event-scale rain gauge quality assessment. The QC procedure in Steiner et al. (1999), for example, consisted of a threetier quality scale where gauges with a zero accumulation were "bad", gauges "[without] any suspicious data" were classified as "good", and any remaining gauges were neither "good" nor "bad." This procedure did not go far enough for our analysis as it would not flag gauge observations that were implausibly high or observation values near zero in areas of heavy rainfall. The QC procedure used by MRMS [as described by Kim et al. (2009)] compares the gauge error for each gauge to the gauge errors within $10 \mathrm{~km}$. If the gauge being evaluated exceeds a set threshold, it is excluded from further analysis. Other QC procedures described by Kim et al. (2009) involve checks for repeating values, excessive missing data, and gauges reporting a zero accumulation during periods of rainfall. This technique could still miss values that were implausibly high or low. Another QC procedure presented by Kondragunta and Shrestha (2006) also is threshold based. All gauges within a 1x1 degree latitude and longitude area are evaluated, and then individual values are compared to the variability of gauges within that area. If gauges exceed a certain threshold, they are excluded. This procedure was more complex than the others but no threshold value was recommended, nor were any examples provided showing gauges removed in separate cases under different thresholds. 


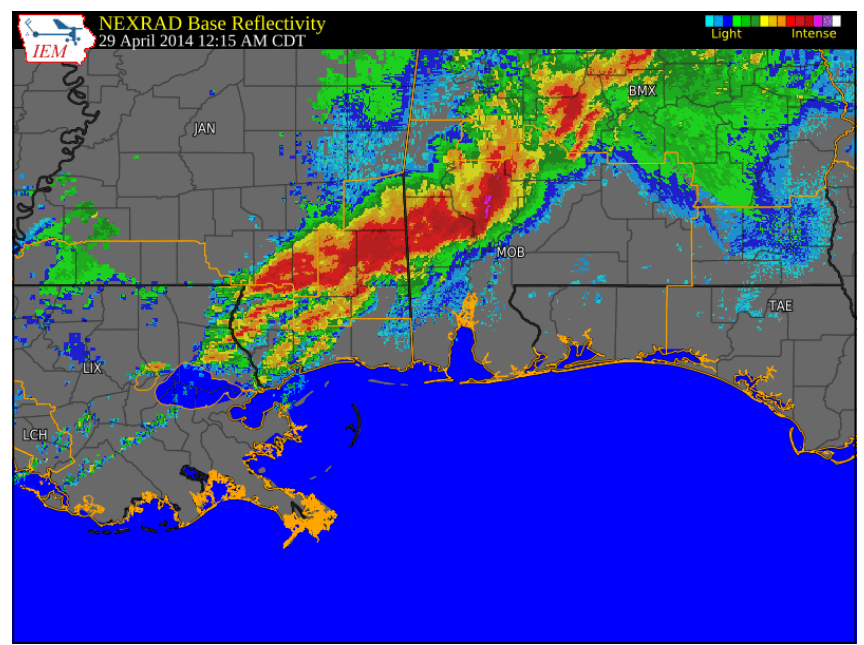

Figure 7. NEXRAD radar image centered on Mobile, Alabama, valid at approximately 0845 UTC 29 April 2014. Click for an animation spanning from approximately 0500 UTC 29 April 2014 to 1200 UTC 29 April 2014, which corresponds to the first wave of rainfall. Graphic and animation from the Iowa Environmental Mesonet (http://mesonet.agron.iastate. edu/GIS/apps/rview/warnings.phtml).

We implemented a QC process using a three-tier scale of "fail," "questionable," or "pass" based upon comparison of individual gauges against the official NWS bias-corrected, best-estimate rainfall data (www. water.weather.gov/precip). Gauges were categorized as "fail" if they recorded $<50 \%$ or $>200 \%$ of the biascorrected radar estimates. "Questionable" gauges recorded $<75 \%$ or $>150 \%$, but not $<50 \%$ or $>200 \%$. Gauges were categorized as "pass" if they recorded rainfall between $75 \%$ and $150 \%$ of the bias-corrected radar estimates. Gauges marked as "fail" were not used in bias-correction of radar rainfall estimates. As a result of the QC process, 42 gauges were flagged as a "fail," 48 gauges were flagged as "questionable," and 166 gauges were flagged as "pass."

\section{c. Gridded Rainfall Data}

Gridded rainfall data were generated by the MRMS system maintained by the National Severe Storms Laboratory (NSSL). The MRMS system obtains and mosaics radar data from sites across the United States, then converts to rainfall rate based upon an estimate of the best radar reflectivity to rainfall (Z-R) relationship for a particular location. Hourly MRMS data were retrieved from the Iowa Environmental Mesonet's

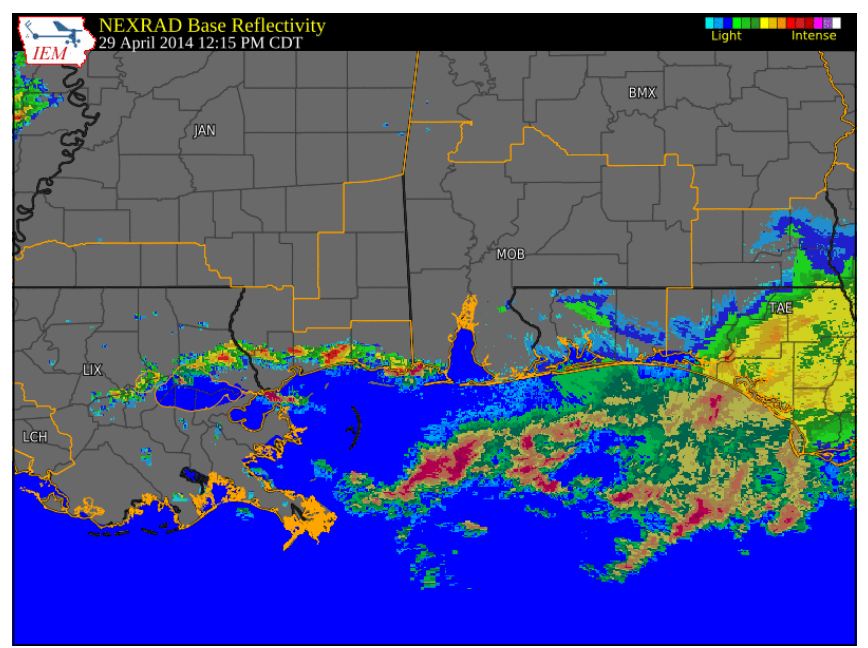

Figure 8. NEXRAD radar image centered on Mobile, Alabama, valid atapproximately0115UTC30April2014. Click for an animation spanning from approximately 1700 UTC 29 April 2014 to 1100 UTC 30 April 2014, which corresponds to the second wave of rainfall. Graphic and animation from the Iowa Environmental Mesonet (http://mesonet.agron.iastate.edu/GIS/apps/rview/ warnings.phtml).

rainfall archive (www.mesonet.argron.iastate.edu/ rainfall) and then accumulated from 1200 UTC 29 April through 1200 UTC 01 May to provide a storm total. The gridded storm total rainfall estimate was then biascorrected using point data that passed QC (as described above). According to this, storm total rainfall greater than $25.4 \mathrm{~cm}$ (10 in) occurred near Mobile, and greater than $38.1 \mathrm{~cm}$ (15 in) occurred near Pensacola (Fig. 10). Just west of Pensacola near Lillian (location of the point observation maximum), rainfall greater than $50.8 \mathrm{~cm}$ (20 in) was estimated using this bias correction technique. Although this storm total rainfall estimate corresponds to a 3 -d period ending at 1200 UTC 01 May 2014, this rainfall estimate could also be described as the maximum 2-d total (within the period) because no one particular location experienced rainfall for more than approximately $48 \mathrm{~h}$.

The addition of crowd-sourced rainfall observations (as described in section 2) generally increased gridded rainfall estimates when compared to the NWS biascorrected, best-estimate rainfall data produced in realtime during the event (Fig. 11). In the vicinity of Lillian, Alabama - the location of maximum observed storm total rainfall - gridded estimates were substantially increased, on the order of 10.2 to $20.4 \mathrm{~cm}$ (4 to 8 in). Throughout northern portions of Pensacola, Florida, 


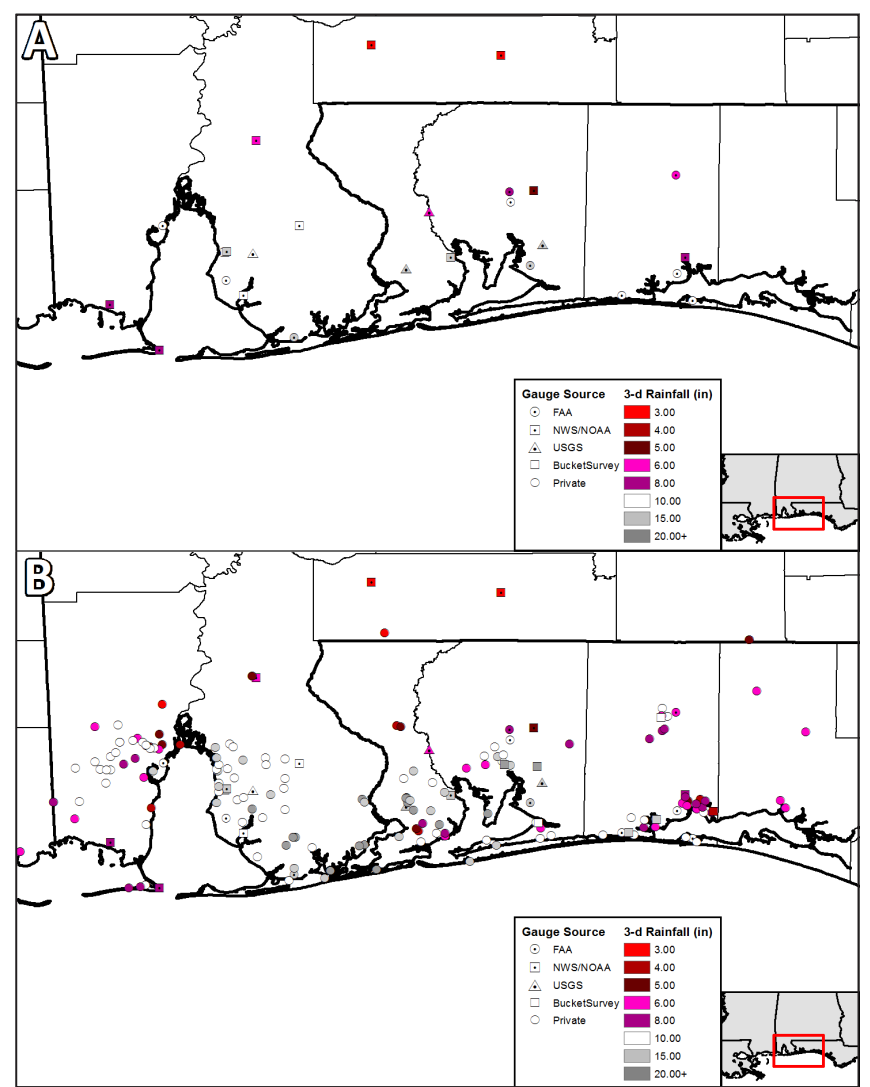

Figure 9. 3-d storm total rainfall observations for 1200 UTC 29 April to 1200 UTC 01 May from only point rainfall observations received by the NWS in real-time (top) and from all point rainfall observations - including those added through crowd-sourcing (bottom). Gauge source is differentiated by symbols and the storm total value is indicated by the fill color. Gauges that failed the QC process (section $3 b$ ) were excluded.

rainfall estimates were increased, but by a reduced magnitude. Rainfall estimates were reduced in some locations, including southern portions of Pensacola, areas along the western side of Mobile Bay, and areas east of Pensacola, due to the addition of observations obtained through crowd-sourcing.

\section{d. Rainfall Frequency Analysis}

Gridded rainfall estimates, such as those found in Fig. 10, can be compared to gridded rainfall frequency estimates to calculate the ARI or AEP for the event. A higher ARI (lower AEP) value is related to a lesser chance of occurrence for that event, thus a higher ARI (lower AEP) is indicative of a more severe event. The ARI for the 3-d storm total rainfall was estimated based upon NOAA Atlas 14 (Perica et al. 2013), a product of the NWS Hydrologic Design Studies Center (HDSC).

Several durations of rainfall were analyzed for this flood event, for both the point observations (gauges) and gridded estimates. Figure 12 shows the estimated AEP/ ARI for the gridded 3-d storm total rainfall beginning at 1200 UTC 28 April 2014 and ending at 1200 UTC 01 May 2014. Because no individual location received rainfall for a duration longer than $48 \mathrm{~h}$, the rainfall estimate was analyzed with 2-d rainfall frequency data. The maximum 2-d ARI value was estimated as at least

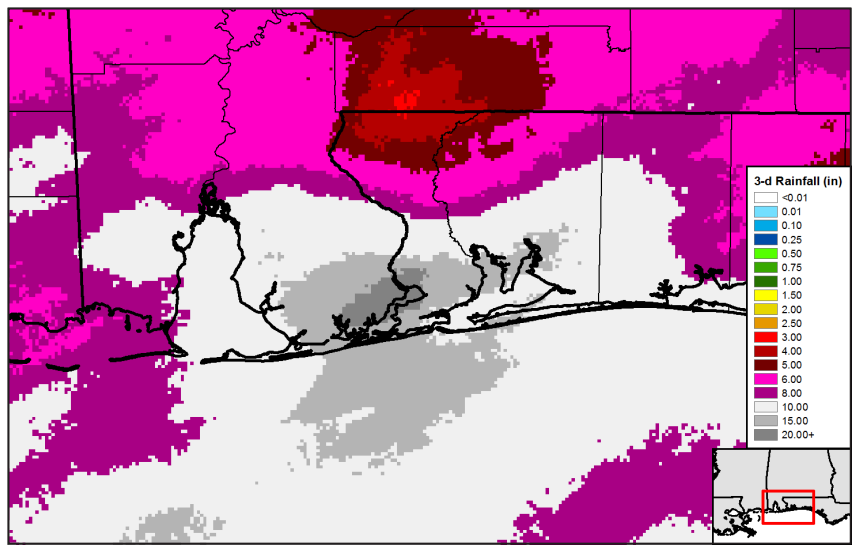

Figure 10. Bias-corrected, gridded rainfall estimates for the $3-d$ period from 1200 UTC 29 April to 1200 UTC 01 May 2014. Gridded rainfall data were derived from MRMS and bias-corrected with all rainfall observations that passed QC. For any one location, rainfall generally occurred over a 2-d period.

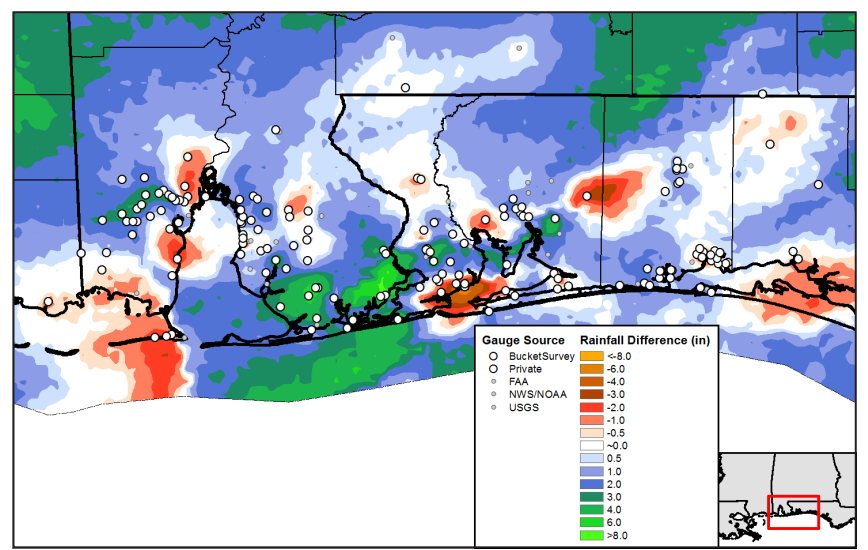

Figure 11. Comparison of the bias-corrected, gridded rainfall estimates from Fig. 10 to the best-estimate rainfall from the NWS (www.water.weather.gov). Orange and red colors correspond to areas where the additional rainfall observations obtained through crowdsourcing reduced the rainfall estimate (compared to the NWS best-estimate). Blue and green colors correspond to areas where the rainfall estimate was increased. 


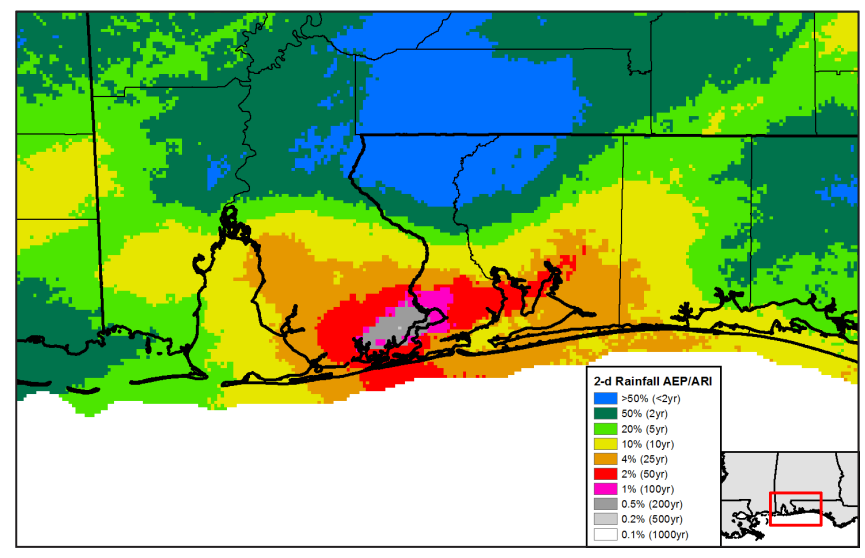

Figure 12. The ARI/AEP for the maximum 48-h gridded rainfall estimate between 1200 UTC 29 April and 1200 UTC 01 May 2014.

a 500 -yr event $(0.2 \%$ AEP) for an isolated area near Lillian, Alabama. For the Mobile and Pensacola areas, the maximum 2-d rainfall ARI value was estimated as greater than a 10 -yr event (10\% AEP) and greater than a 50 -yr event ( $2 \%$ AEP), respectively. Portions of at least six counties in coastal Alabama and Florida experienced 2-d rainfall of at least a 10-yr event (10\% AEP).

Rainfall estimates accumulated over fixed intervals of time (such as the gridded 3-d storm total rainfall used for the analysis in Fig. 10) can be problematic for frequency analysis however, because the fixed interval may not include the true maximum of the event. For example, heavy rainfall that crosses from one day (1200 UTC to 1200 UTC or midnight to midnight) into the next may have a low ARI for those individual days, but the 24-h total spanning the actual rain event may be much higher, causing an underestimate in the ARI. To address this, running accumulations for the 1-h, 2-h, 3-h, 6-h, 12-h, and 24-h durations were calculated for each point observation of rainfall (gauges). A preliminary analysis from the HDSC indicated the maximum 6-h rainfall as a $200-\mathrm{yr}(0.5 \% \mathrm{AEP})$ event on the western portion of the Pensacola metropolitan area, based upon far fewer gauges than were collected for our analysis (www.nws.noaa.gov/ohd/hdsc/aep_storm analysis/10 Pensacola_2014.pdf). In contrast, utilizing data from the nearly 200 gauges collected for this analysis (as described previously), the maximum 6-h rainfall exceeded the 1,000-yr ARI $(0.1 \%$ AEP) at multiple point locations. The analysis of the shorter durations of rainfall available from the gauge observations yielded higher ARIs (lower AEPs) than the gridded storm total rainfall. The rainfall durations with the highest ARI (lowest AEP) were generally between $6 \mathrm{~h}$ and $24 \mathrm{~h}$. A

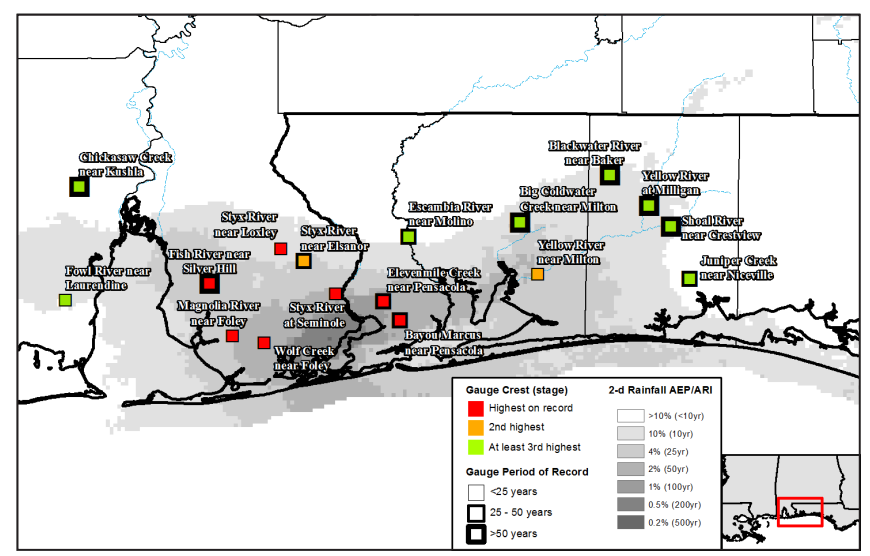

Figure 13. USGS gauge locations in the impacted area overlaid upon the maximum 48-h rainfall ARI. Darker shading indicates higher ARI (lower AEP). The USGS gauge locations are colored by gauge height; green boxes indicate a gauge crest that was at least the third highest on record, orange boxes indicate the second highest crest on record, and red boxes indicate that this event set a new record (USGS). The gauge period of record is shown based on the width of the border where the thickest border corresponds to the longest period of record.

selection of gauge observations and ARIs from across the affected area is shown in Table 1.

\section{Flooding Impact Analysis}

Water level data for USGS stream gauge locations from Mobile to the Western Florida Panhandle were collected (Fig. 13). These hydrologic stations measured gauge height during the event and range in years of service from 3 to 62 years. Peak streamflow was estimated by the USGS based upon gauge height measurements. Seven USGS hydrologic stations recorded the maximum peak streamflow during this flooding event.

Fish River near Silver Hill, Alabama, has the longest period of record for water-level data (in service since December of 1953) and Juniper Creek at State Highway 85 near Niceville, Florida, has the second longest period of record (in service since May of 1966). Both gauges serve as reliable data sources for water levels for comparing the historic nature of this flood to previous events. Styx River at Seminole, Alabama, Styx River near Loxley Alabama, Magnolia River near Foley, Alabama, and Wolf Creek below Foley, Alabama, each have less than 15 years of records, so the rank of this flood event should be used with caution. The crest at the Bayou Marcus Creek near Pensacola 
Table 1. Maximum 3-, 6-, 12-, and 24-h rainfall ARIs from private and official rainfall gauges

\begin{tabular}{|c|c|c|c|c|}
\hline & $\begin{array}{l}\text { Max 3-h } \\
\text { Total cm (in) }\end{array}$ & $\begin{array}{l}\text { Max 6-h } \\
\text { Total cm (in) }\end{array}$ & $\begin{array}{l}\text { Max 12-h } \\
\text { Total cm (in) }\end{array}$ & $\begin{array}{l}\text { Max 24-h } \\
\text { Total cm (in) }\end{array}$ \\
\hline $\begin{array}{l}\text { Davis (dwl458) } \\
\text { Foley, AL } \\
\text { Rainfall Total } \\
\text { ARI }\end{array}$ & $\begin{array}{l}21.74(8.56) \\
>200-\mathrm{yr}\end{array}$ & $\begin{array}{l}30.71(12.09) \\
>200-\mathrm{yr}\end{array}$ & $\begin{array}{l}35.99(14.17) \\
>100-\mathrm{yr}\end{array}$ & $\begin{array}{l}49.99(19.68) \\
>500-\mathrm{yr}\end{array}$ \\
\hline $\begin{array}{l}\text { Private Weather Station } \\
\text { Lillian, AL } \\
\text { Rainfall Total } \\
\text { ARI } \\
\end{array}$ & $\begin{array}{l}29.95(11.79) \\
>1000-\mathrm{yr}\end{array}$ & $\begin{array}{l}47.42(18.67) \\
>1000-\mathrm{yr}\end{array}$ & $\begin{array}{l}66.29(26.09) \\
>1000-\mathrm{yr}\end{array}$ & $\begin{array}{l}70.21(27.64) \\
>1000-\mathrm{yr}\end{array}$ \\
\hline $\begin{array}{l}\text { WU PWS (KALILLI1) } \\
\text { Lillian, AL } \\
\text { Rainfall Total } \\
\text { ARI } \\
\end{array}$ & $\begin{array}{l}21.54(8.48) \\
>200-\mathrm{yr}\end{array}$ & $\begin{array}{l}32.64(12.85) \\
>200-\mathrm{yr}\end{array}$ & $\begin{array}{l}47.74(18.40) \\
>500-\mathrm{yr}\end{array}$ & $\begin{array}{l}49.20(19.37) \\
>200-\mathrm{yr}\end{array}$ \\
\hline $\begin{array}{l}\text { WU PWS (KFLMILTO12) } \\
\text { Milton, FL } \\
\text { Rainfall Total } \\
\text { ARI } \\
\end{array}$ & $\begin{array}{l}21.03(8.28) \\
>200-y r\end{array}$ & $\begin{array}{l}26.57(10.46) \\
>100-\mathrm{yr}\end{array}$ & $\begin{array}{l}33.50(13.19) \\
>100-\mathrm{yr}\end{array}$ & $\begin{array}{l}37.77(14.87) \\
>50-\mathrm{yr}\end{array}$ \\
\hline $\begin{array}{l}\text { KNDZ } \\
\text { Milton, FL } \\
\text { Rainfall Total } \\
\text { ARI } \\
\end{array}$ & $\begin{array}{l}15.82(6.23) \\
>50-\mathrm{yr}\end{array}$ & $\begin{array}{l}15.82(6.23) \\
>50 \text {-yr }\end{array}$ & $\begin{array}{l}20.49(10.43) \\
>50-\mathrm{yr}\end{array}$ & $\begin{array}{l}27.94(11.00) \\
>10-\mathrm{yr}\end{array}$ \\
\hline $\begin{array}{l}\text { KNFJ } \\
\text { Navarre, FL } \\
\text { Rainfall Total } \\
\text { ARI }\end{array}$ & $\begin{array}{l}26.62(10.48) \\
>500-\mathrm{yr}\end{array}$ & $\begin{array}{l}26.62(10.48) \\
>500-\mathrm{yr}\end{array}$ & $\begin{array}{l}39.47(15.54) \\
>50-\mathrm{yr}\end{array}$ & $\begin{array}{l}43.76(17.23) \\
>100-\mathrm{vr}\end{array}$ \\
\hline $\begin{array}{l}\text { Davis (kf4dvf) } \\
\text { Pensacola, FL } \\
\text { Rainfall Total } \\
\text { ARI } \\
\end{array}$ & $\begin{array}{l}25.10(9.88) \\
>500-\mathrm{yr}\end{array}$ & $\begin{array}{l}25.10(9.88) \\
>500-\mathrm{yr}\end{array}$ & $\begin{array}{l}54.13(21.31) \\
>1000-\mathrm{yr}\end{array}$ & $\begin{array}{l}56.82(22.37) \\
>200-\mathrm{yr}\end{array}$ \\
\hline $\begin{array}{l}\text { WU PWS (KFLPENS46) } \\
\text { Pensacola, FL } \\
\text { Rainfall Total } \\
\text { ARI } \\
\end{array}$ & $\begin{array}{l}25.12(9.89) \\
>500-\mathrm{yr}\end{array}$ & $\begin{array}{l}25.12(9.89) \\
>500-\mathrm{yr}\end{array}$ & $\begin{array}{l}46.28(18.22) \\
>200-\mathrm{yr}\end{array}$ & $\begin{array}{l}48.39(19.05) \\
>200-\mathrm{yr}\end{array}$ \\
\hline $\begin{array}{l}\text { Davis (Siguenzacove) } \\
\text { Pensacola, FL } \\
\text { Rainfall Total } \\
\text { ARI } \\
\end{array}$ & $\begin{array}{l}25.78(10.15) \\
>500-\mathrm{yr}\end{array}$ & $\begin{array}{l}25.78(10.15) \\
>500-\mathrm{yr}\end{array}$ & $\begin{array}{l}46.74(18.40) \\
>500-\mathrm{yr}\end{array}$ & $\begin{array}{l}47.32(18.63) \\
>100-\mathrm{yr}\end{array}$ \\
\hline
\end{tabular}

gauge was impacted by the dam failure at Crescent Lake and the gauge was overtopped, meaning that the crest observation was estimated indirectly (Rodriguez et al. 2015).

During this event a multitude of reports ranging from flooded roadways to a dam failure at Crescent Lake were recorded (Fig. 14). Twenty reports of flooding were sent to the NWS during the event via law enforcement, emergency managers, and other trained spotters. Once the event had ended, an effort to collect additional data through crowd-sourcing began. There were 127 reports obtained via media reports, social media posts, blogs, and post-flood event reports as a result of this effort. Reports of flooding were then categorized by impact similar to the methods of Lincoln (2014). There were 54 reports of flooded roadways (of which 10 were reported as "major" with several feet of water covering a road or a major highway inundated) and 41 reports of roadway damage or washouts. During this event, 43 reports of flooded structures were recorded and two water rescues were made. Reports of both flooded roadways and structures were scattered throughout the flood area, with the highest density in the Pensacola area. The Crescent Lake dam failure caused water rescues, several flooded structures, and a couple roadway washouts. Additional examples of washouts occurred near the lake. In particular, Blue Springs Drive was completely eroded

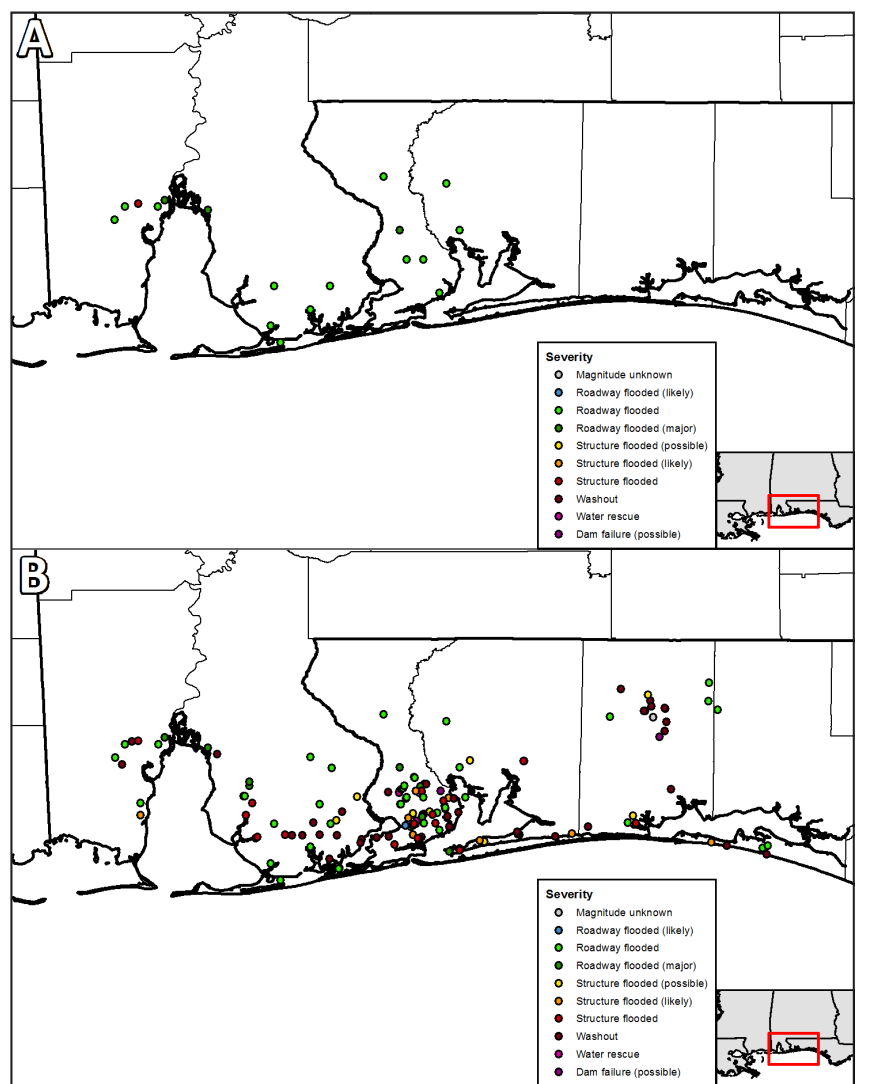

Figure 14. Flash flood reports for the late April 2014 flood event collected by the NWS during the event (top) and all flash flood reports - including those added through crowd-sourcing (bottom).

away for a multiple-block section (Escambia County 2016).

\section{Discussion}

The addition of numerous rainfall locations yielded a finer spatial scale rainfall analysis in comparison to utilizing only gauges available in real-time. From coastal Alabama into the western Florida Panhandle, only 19 rain gauges were available to provide realtime observations to the NWS. By adding in daily rainfall observations such as cooperative observers and CoCoRaHS, the number of rain gauges increased to 104. Through crowd-sourcing (usage of private weather networks and a bucket survey), the number of point rainfall locations reached 245, a figure approximately double that of official stations alone, even after the 42 locations that failed QC were removed.

Through this analysis it was determined that rainfall ARIs/AEPs were more extreme than analyzed by preliminary reports. It also was noted that the extreme 
rainfall amounts occurred over numerous durations ranging from $3 \mathrm{~h}$ to $3 \mathrm{~d}$. The analysis by the HDSC estimated that the maximum $6-\mathrm{h}$ rainfall was a $200-\mathrm{yr}$ $(0.5 \%$ AEP) event for a small area just west of Pensacola. Utilizing the substantially larger collection of point observations collected for this analysis, it was estimated that point observations of 6-h rainfall were at least a 1,000 -yr $(0.1 \%$ AEP) event at multiple gauges near Pensacola. Rainfall observations from point locations were slightly higher than the gridded estimates, and thus yielded higher ARI (lower AEP) values, especially for durations of $6 \mathrm{~h}$ to $24 \mathrm{~h}$. The maximum gridded rainfall estimate near Lillian, Alabama, just west of Pensacola, was also analyzed as at least a $500-y r(0.1 \%$ AEP $)$ event for the entire three days ending at 1200 UTC 1 May 2014.

Utilizing such a large amount of point rainfall data, some level of QC was required. Unfortunately, there is uncertainty associated with any QC algorithm or method. We chose a conservative approach to avoid a situation where possibly accurate gauges higher than surrounding gauges would be removed. In extreme rainfall situations gauges often fail by being too low rather than too high. Although the increased number of gauges may increase the overall precision in the rainfall analysis, uncertainty likely remains that is difficult to quantify, especially with gauges obtained via private locations and the public. QC thresholds that are too broad may allow additional accurate high gauges to be included at the expense of including additional inaccurate low gauges. In contrast, thresholds that are too narrow would exclude more low gauges but potentially flag plausible high values as inaccurate. Four areas switched from increased values to decreased values because of addition of the private weather station networks (AWS, WU, Davis) to the bias correction. For each of these areas, one to four gauges were flagged as "questionable" by the QC process (Fig. 15). Although this does not necessarily speak to the accuracy of those gauges, it does highlight that in some cases erroneous gauges can make it through objective QC techniques and alter subsequent rainfall analyses.

The site with the highest rainfall total $(73.15 \mathrm{~cm}$ or 28.8 in) was a private weather station located near Lillian, Alabama. In the QC process this gauge was flagged as "Questionable." To investigate the validity of the value, this report received additional scrutiny. There were few additional gauge observations in the immediate surrounding area. Site KALILLI1, approximately 1.5 $\mathrm{km}(1.0 \mathrm{mi})$ to the west, reported $51.82 \mathrm{~cm}(20.4 \mathrm{in})$.
The nearest official gauge, USGS site ELVF1, was $17.8 \mathrm{~km}(11.0 \mathrm{mi})$ to the northeast and recorded 40.64 $\mathrm{cm}$ (16.00 in). In order to address the validity of the maximum observation, rainfall rates were compared to these nearby stations that passed the QA/QC process. Gauges that were used for comparative purposes were KALILLI1 (WU PWS), KF4DVF (Davis), ELVF1 (USGS), and another private weather station within 3 $\mathrm{km}$ (approximately $2 \mathrm{mi}$ ) of ELVF1. QC methods from other studies (see section $3 \mathrm{~b}$ ) were also used to evaluate the maximum observed rainfall near Lillian. The results of these alternative $\mathrm{QC}$ checks are: 1) for the Q2/

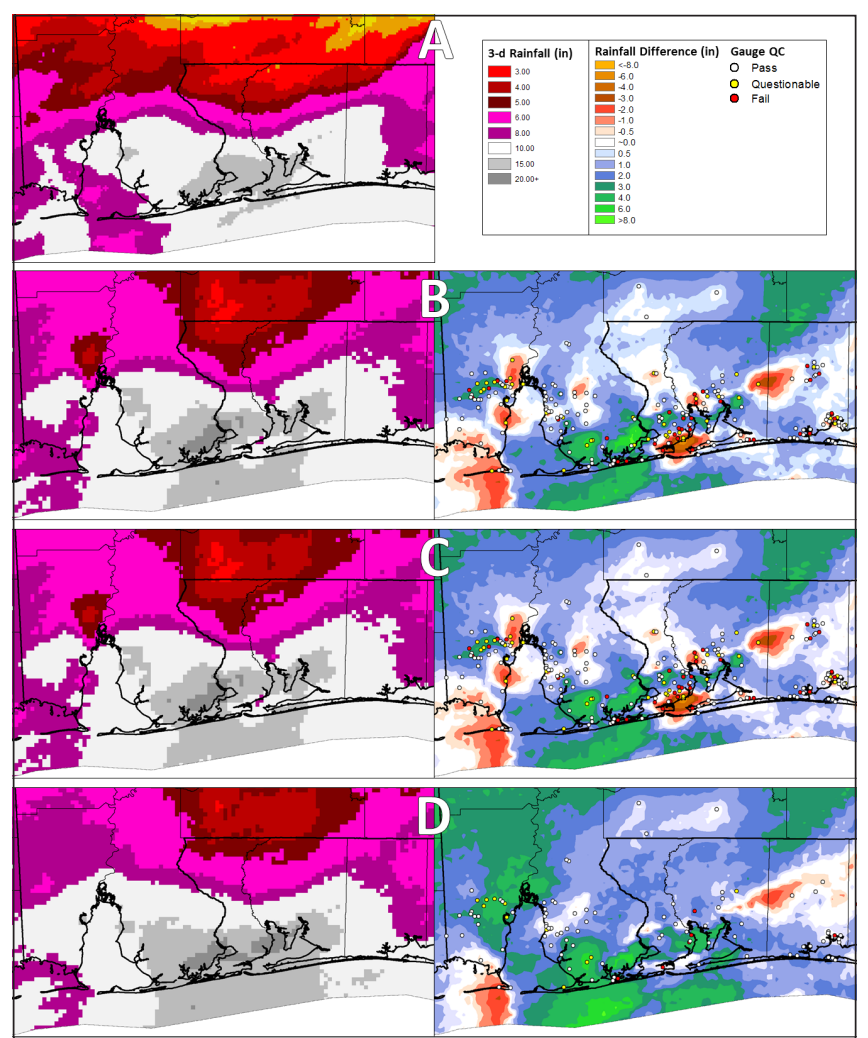

Figure 15. Sensitivity analysis comparing results based on selected subsets of gauge observations. Biascorrected, gridded rainfall estimates for the 3-d period from 1200 UTC 29 April to 1200 UTC 01 May 2014 (left; similar to Fig. 10) and the difference between the best-estimate rainfall from the NWS (A) to the biascorrected, gridded rainfall estimates (right; similar to Fig. 11). Rainfall analysis utilizing all gauges that did not fail QC (B), rainfall analysis utilizing all gauges that did not fail $\mathrm{QC}$ except for the rainfall maximum near Lillian, Alabama (C), and rainfall analysis utilizing all gauges except the rainfall maximum near Lillian, Alabama, and those obtained from the AWS, WU PWS, and Davis networks (D). 
MRMS procedure presented in Kim et al. (2009), "fail," 2) for the Kondragunta and Shrestha (2006) procedure, "pass" (by a large margin), and 3) for other general QC checks (repeating values, zero values, etc.) in Kim et al. (2009), "pass." Because of the differing QC results for the Lillian rainfall observation, a sensitivity analysis was performed to determine the impact on the biascorrected rainfall analysis if the "questionable" rainfall maximum was removed. The resulting change from the removal of the Lillian, Alabama, private weather station observation (Fig. 15C) was entirely within the $50.8 \mathrm{~cm}$ (20 in) rainfall contour which, although very isolated areas near the gauge changed by up to $8.9 \mathrm{~cm}(3.5$ in), yielded no change to the rainfall values illustrated by Fig. 10. Also in support of keeping the Lillian observation, it was found that the radar-only rainfall estimate from MRMS placed the storm total maximum within $3.2 \mathrm{~km}$ (2 mi) of the observation location.

QC of rainfall gauges is difficult and numerous studies exist that attempt to identify and quantify the sources of gauge errors. Studies have shown that due to microscale variability or random measurement errors even co-located gauges of similar design can yield different precipitation intensities and accumulations (Krajewski et al. 2003; Datta et al. 2003). These errors increase with distance and this increase is faster for heavier rainfall rates (Habib and Krajewski 2002). Although the rain rate for the gauge in question was higher than the neighboring sites (at least 20\% during heaviest rainfall periods), no obvious spurious data were noted (Fig. 16). Not all QC methods suggested issues with the rainfall report and the gauge owner was deemed highly credible. Because of issues with rainfall gauges during extreme rain rates, the data seemed plausible and was thus included in the analysis.

We also further tested the sensitivity of the multisource, bias-corrected rainfall analysis to the addition of private rainfall networks obtained through crowdsourcing. The rainfall analysis was not very sensitive to removal of individual gauges (such as the private weather station observation near Lillian, Alabama; Fig. 15C), but the removal of entire networks (such as AWS, WU PWS, and Davis) may cause notable changes (Fig. 15D). It was also observed that some areas with the most pronounced changes in rainfall due to the addition of crowd-sourced observations were in areas with gauges marked as "questionable." It is not clear if these changes are due to microscale variability with rain gauge measurements, gauge under-estimation due to extreme rainfall rates, unknown gauge errors, or

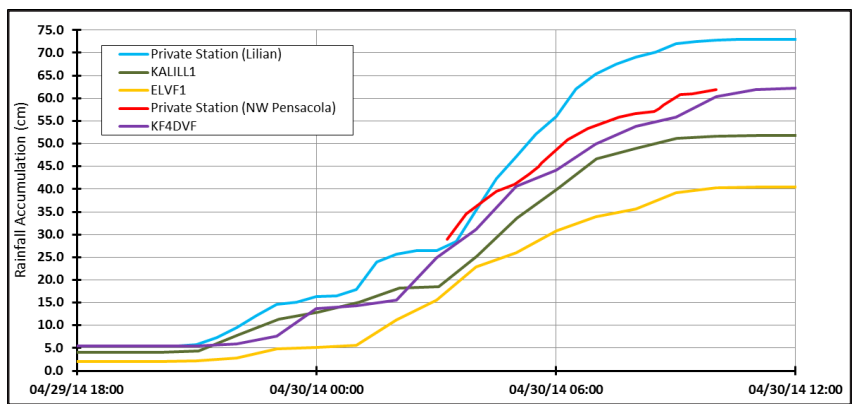

Figure 16. Rainfall hyetographs from 1800 UTC 29 April 2014 to 1200 UTC 30 April 2014 for point rainfall observations surrounding the private observer in Lillian, Alabama, which reported the maximum storm total value of $73.15 \mathrm{~cm}$ (28.8 in).

some combination.

The addition of more than 100 reports of flood impacts through crowd-sourcing also helped to highlight the severity of the event. Although a handful of USGS gauge locations did set new records, these are valid for point locations only; by adding the crowd-source data it was shown that impacts to structures and infrastructure were widespread over multiple counties. Of particular note, two counties with no official reports of flooding actually did experience major flooding (inundation of structures), as evidenced by reports collected via social media.

\section{Conclusions}

The late April 2014 flood that spanned from the Alabama coastline to the Western Florida Panhandle was caused by a slow-moving cold front that interacted with ample moisture and instability. Parallel storm vectors resulted in the training of thunderstorms causing locally extreme rainfall. Crowd-sourcing yielded more than 200 additional rainfall reports and more than 100 additional flood impact reports, which improved the examination of severity and scope of this event. Storm total rainfall estimates in the Mobile, Alabama, area were in excess of $25.4 \mathrm{~cm}$ (10 in) with rainfall estimates in excess of $50.8 \mathrm{~cm}$ (20 in) in the Pensacola, Florida, area. ARI/AEP calculations showed the observed rainfall maximum of $73.15 \mathrm{~cm}$ (28.8 in) near Lillian, Alabama, was a $500-y r(0.2 \%$ AEP) event for the $3-d$ rainfall total. Further analysis indicated that multiple point locations experienced at least a $500-y r(0.2 \%$ AEP) event for rainfall durations of $3 \mathrm{~h}$ to $24 \mathrm{~h}$, and a few sites experienced at least a 1,000-yr $(0.1 \%$ AEP) event for some durations. This heavy rainfall resulted in 
several gauge height and streamflow records, with some flows that nearly doubled previous records. This event resulted in extensive damage and multiple fatalities, as evidenced not only by official flood reports, but also the numerous crowd-sourced reports mined from news reports, social media, and other web sources. Because of the difficulty in utilizing multiple, independent weather networks for additional rainfall observations, future work should include development and assessment of objective rain gauge QC techniques and evaluation of potential errors and uncertainty caused by the addition of these stations.

Acknowledgments. The authors would like to recognize the staff at Davis Instruments for their generosity and hard work retrieving data manually from their private weather station data repository. The authors would also like to acknowledge Weather Underground, Earth Network's WeatherBug, and the CoCoRaHS network as sources for additional private weather station data. The large volume of easily accessible data from the Iowa Environmental Mesonet was found to be particularly helpful to the authors. The large number of individuals who provided crowd-sourced data in the form of local storm reports, photos, videos, and rainfall data should also be thanked for their valuable information that allowed for a better understanding of the event.

The authors would also like to thank Dr. Emad Habib, NWA journal editors, and the two anonymous reviewers for their assistance in improving this manuscript during the peer review process.

\section{REFERENCES}

Datta, S., W.L. Jones, B. Roy, A. Tokay, 2003: Spatial variability of surface rainfall as observed from TRMM field campaign data. J. Appl. Meteor., 42, 598-610, CrossRef.

Escambia County. (n.d.). Crescent Lake / Blue Springs. Retrieved May 23, 2016, from http://myescambia.com /government/projects/150440

Gourley, J. J., J. M. Erlingis, T. M. Smith, K. L. Ortega, and Y. Hong, 2010: Remote collection and analysis of witness reports on flash floods. J. Hydrol., 394, 53-62, CrossRef.

Habib, E., and W. F. Krajewski, 2002: Uncertainty analysis of the TRMM ground-validation radar-rainfall products: Application to the TEFLUN-B field campaign. J. Appl. Meteor., 41, 558-572, $\underline{\text { CrossRef. }}$
Iowa Environmental Mesonet (IEM), RADAR \& NWS Warnings. (n.d.). Retrieved May 02, 2016, from https://mesonet.agron.iastate.edu/GIS/apps/rview/ warnings.phtml

Kim, D., E. Tollerud, S. Vasiloff, and J. Caldwell, 2009: Comparison of Manual and Automated Quality Control of Operational Hourly Precipitation Data of the National Weather Service. 23rd Conf. on Hydrology, Phoenix, AZ, Amer. Meteor. Soc., 6.3. [Available online at https://ams.confex.com/ams/89annual/ techprogram/paper_146869.htm.]

Kondragunta, C. R., and K. Shrestha, 2006: Automated Real-Time Operational Rain Gauge Quality-Control Tools in NWS Hydrologic Operations. 20th Conf. on Hydrology, Atlanta, GA, Amer. Meteor. Soc., 2.4. [Available online at http://ams.confex.com/ams/ Annual2006/techprogram/paper 102834.htm.]

Krajewski, W.F., G. J. Ciach, and E. Habib, 2003: An analysis of small-scale rainfall variability in different climatic regimes. Hydrol. Sci. J., 48, 151-162, CrossRef.

Lincoln, W. S., 2014: Analysis of the 15 June 2013 isolated extreme rainfall event in Springfield, Missouri. J. Operational Meteor., 2, 233-245, CrossRef.

, J. Brazzell, M. Pope, R. McNeil, D. Schlotzhauer, K. Costanza, J. Graschel, and S. Van Cooten, 2013: 2012 Southeast Louisiana and Southern Mississippi Flooding Due to Hurricane Isaac. NWS River Forecast Center Technical Paper. Available online at https://www.weather.gov/media/lmrfc/tech/2012 Hurricane Isaac Flooding 2014 10_22.pdf.

National Weather Service, 2012: National Weather Service Directives Manual 10-950. National Weather Service, Silver Spring, MD. Retrieved December 1, 2016 from http://www.nws.noaa.gov/directives/sym pd00101001curr.pdf

Parzybok, T. W., and B. L. Shaw, 2012: Forecast average recurrence interval precipitation maps for the United States: A new way of communicating the location and magnitude of high impact precipitation events. Preprints, 26th Conf. on Hydrometeorology, New Orleans, LA, Amer. Meteor. Soc., 5.1. [Available online at http://ams.confex.com/ams/92Annual/webprogram/ Paper196778.html.]

, B. Clarke, and D. M. Hultstrand, 2011: Real-time average recurrence interval rainfall maps for the U.S. Preprints, 39th Conf. on Broadcast Meteorology, Oklahoma City, OK, Amer. Meteor. Soc., 6.1. [Available online at http://ams.confex.com/ams/ 39BROADCAST/webprogram/Paper189032.html.]

Perica, S., and Coauthors, 2013: NOAA Atlas 14 Precipitation-Frequency Atlas of the United States. NWS HDSC, Volume 9, Version 2, 171 pp. [Available online at http://www.nws.noaa.gov/oh/hdsc/PF documents/Atlas14_Volume9.pdf.] 
Rodriguez, R. W., R. Kane, D. Sumner, and R. S. Padgett, 2015: Caribbean-Florida Water Science Center Newsletter Volume 2, Spring 2015. U.S. Geological Survey Caribbean-Florida Water Science Center Newsletter, 2, 2. Retrieved May 15, 2016, from http://pr.water.usgs.gov/newsroom/newsletters/USGS Carrib-FL Newsletter Spring-2015.pdf

Steiner, M., J. A. Smith, S. J. Burges, C. V. Alonso, and R. W. Darden, 1999: Effect of bias adjustment and rain gauge quality control on radar rainfall estimation. Water Resour. Res., 35, 2487-2503, CrossRef. 